\title{
The Impact of International Knowledge Search on Innovation Performance: Moderated by Search Intensity
}

\author{
Hang WU \\ Business School, East China University of Political Science and Law, 201620, Shanghai, China \\ wuhang0503@163.com
}

Keywords: international knowledge search, search intensity, innovation performance.

\begin{abstract}
In the era of knowledge economy, firms need to search outside to obtain strategic and complementary resources to innovate. However, existing research on open innovation mainly focuses on local knowledge search and ignores to answer the question that how firms search outside firm boundary. Based on the attention theory, we divide external knowledge search process into two parts, namely search selection and search intensity. This paper examines how international knowledge search and search intensity help enhance innovation performance in China's emerging economy. The result shows that international knowledge search and search intensity both are positively related to innovation performance, and search intensity positively moderates the relationship between international knowledge search and innovation performance. Theoretical and managerial implications are discussed.
\end{abstract}

\section{Introduction}

Open innovation has emerged as the main innovation mode in the era of knowledge economy [1]. Because of the increasing innovation complexity and technological change speed, firms need to search outside firm boundary to get necessary strategic assets and complementary resources to promote innovation [2] [3] [4]. Nowadays, theoretical research has verified the strategic importance of external knowledge source. For example, Laursen and Salter [3] empirically demonstrate that searching widely and deeply in a certain degree can promote firms' innovation performance based on England manufacturing firms. Chen et al. [5] obtain the similar results through empirically investigating Chinese firms. In spite of the large body of evidence documenting the influence of external search on innovation outcomes, many previous studies have focused their attention on sources of knowledge within a firm's national market, with the knowledge beyond national boundaries ignored [2] [3] [4] [5].

Except that, existing research just answers the question that firms should search knowledge outside firm boundary, but ignores to uncover the search method [2] [3] [5]. In other words, little research has explored the characteristics of external search process and rather has focused on asking how firms search outside firm boundary. According to the attention theory, the search process is more than search selection, but also includes devoting time and energy to the selected location [6] [7]. When firms select to search somewhere, it means that we have determined the search place and deployed certain attention to the place [8]. Therefore, in order to comprehensively explore the impact of external knowledge search on innovation performance, it is necessary to introduce the attention theory into external knowledge search literature.

To address these research gaps, this article divides the search process into two parts, including search selection and search intensity, and examines how international knowledge search and search intensity independently and jointly are related to innovation performance. This research contributes to existing open innovation literature by uncovering the external knowledge search process, demonstrating the importance of international innovative source and highlighting that search selection should march with search intensity. The research result can help guild the external knowledge search and improve innovation performance. 


\section{Theory and Hypotheses}

\section{External knowledge search process: search selection and search intensity}

Following the logic of attention theory, attention includes two underlying components: attention selection and attention intensity [6] [7]. In everyday language, attention both refers to amount and intensity ${ }^{[8]}$. When we focus our attention on something, it means that we select to focus on it and direct our energy and time to those things. External knowledge search is the controlled and proactive process of attending to new knowledge and information [8]. During search outside, firms deploy their attention to identify and integrate knowledge from other partners, referring to select the search location and pay attention to it. Following this logic, we divide the search process into two components: search selection and search intensity, with the former focusing on the search location firms select to direct their attention and the latter emphasizing the search effort and persistence firms use. In this paper, we mainly focus on international knowledge search, and search intensity mainly refers to the efforts firms pay to the search process.

\section{International knowledge search and innovation performance}

International knowledge search promotes innovation from two aspects. On the one hand, firms can learn and get resources from foreign counterparts. Zahra et al. ${ }^{[8]}$ demonstrate that foreign cooperation can enhance the depth, scope and speed of technological learning. Kafouros and Forsans [9] argue that firms can get lots of novel knowledge from foreign markets which can greatly enhance innovation. On the other hand, after entering into fireign markets, firms face tight competitive pressure from foreign counterparts and diverse demands from foreign customers, which compels firms to increase R\&D intensity and try their best to innovate to meet customes needs [10] [11]. Therefore, we can conclude that international knowledge search provide firms with a lot of complementary resources and learning opportunity, and competitive pressure which help and compel firms to innovate. Based on these arguements, we predict that:

\section{$H_{1}$ : International knowledge search is positively related to innovation performance.}

\section{Search intensity and innovation performance}

Search intensity refers to the extent of investment in search activities. High search intensity provides increased information processing capacity [7]. When firms are searching information and knowledge to develope innovative products, the increases in search intensity can increase searcher's interpretation and integration capacities which will help firms to detect, develop, and deploy new products. Specifically, high search intensity in searching knowledge and information provides firms with strong capacity to categorize new information and knowledge, and infer connections between different bits of information, and reach a deeper understanding of the information's usefulness, which will finally promote innovation performance [8]. Except that, high search intensity in searching knowledge and information can make firms know more about the internal and external environment which can also help firms make timely and correct innovation decision. Therefore, we predict that:

\section{$\mathrm{H}_{2}$ : Search intensity is positively related to innovation performance.}

\section{The moderating effect of search intensity on the relationship between international knowledge search and innovation performance}

The effect of international knowledge search on innovation depends on search intensity. When searching in foreign markets, firms will obtain a lot of novel and advanced information which is always unfamiliar and sophisticated to domestic firms, surpassing the capability of domestic firms to absorb [11]. Then if domestic firms want to identify and integrate international knowledge, they have to search in high intensity, devoting enough energy and time to process it. Therefore, we can see international knowledge search compels firms to devote enough search intensity to the process because high search intensity can help firms offset the information-processing limitations[10] [11]. However, if firms do not 
search in high intensity in foreign markets, firms may not interpret novel information generated. Therefore, we predict that:

$\mathrm{H}_{3}$ : Search intensity positively moderates the relationship between international knowledge search and innovation performance.

\section{Methodology}

\section{Sample and Data Collection}

We use questionnaires to collect data from Chinese manufacturing firms. We send questionnaires to top managers of the sampled firms using email and letter. Before sending questionnaires, we make a call to the top managers, explain the research purpose and ask for their approval. After one week of sending questionnaires, we once call the top managers and make sure that they have received the questionnaires. Finally, we received 219 valid questionnaires. The responding firms are mainly distributed in industries including electronic information (29.68\%), special equipment manufacturing (20.55\%), transportation equipment manufacturing $(12.33 \%)$, ordinary machinery manufacturing $(11.42 \%)$, metal product $(9.13 \%)$, and others $(16.89 \%)$. The results of the Harman's one-factor test indicate that the common method bias is not a problem in our analysis.

\section{Measures}

The dependent variable is innovation performance (IP) . Following the approach of Chen et al. [5] Zhang and Li [12], we used six items to measure innovation performance which mainly describe the number and sales of new products, the number of patent applications. The specific measurement items can be seen in table 1.

The independent variable is international knowledge search (IKS) and search intensity (SI). Following the approach of Laursen and Salter ${ }^{[3]}$ and Chen et al. [5], we use five items to measure international knowledge search which reflect the extent of their cooperation ties with foreign customers, suppliers, competitors, university and research institutions, and innovation intermediaries. Following the approach of Li et al. [7], we use three items to measure search intensity which reflects the extent to which firms devote time and energy to search rather than to other activities. The specific measurement items of international knowledge search and search intensity can be seen in table 1 .

We controlled for the following variables, including firm size, firm age, R\&D intensity, industry type. Firm size (FS) is the natural log of the number of employees. Firm age (FA) is the number of years since the firm was founded. $R \& D$ intensity $(R \& D)$ is the percentage of $R \& D$ expenditures in total sales. We introduce five industry dummy to control the industry effect, with industry (Ind) 1, 2, 3, 4, 5 indicating electronic information, special equipment manufacturing, transportation equipment manufacturing, percent in ordinary machinery manufacturing, metal product.

\section{Reliability and Validity of the Constructs}

This study assessed the reliability of international knowledge search, search intensity and innovation performance with Cronbach's alpha. The alpha values for international knowledge search, search intensity and innovation performance are $0.964,0.903$ and 0.985 respectively, which indicate a good reliability.

The validity of international knowledge search, search intensity and innovation performance is tested with a confirmatory factor analysis. The results of the three-factor confirmatory factor analysis show that the model fits the data well $\left(\chi^{2}=167.497 ; \chi^{2} / \mathrm{df}=2.263\right.$, bentler non-normed fit index $(\mathrm{NNFI})=$ 0.969 , comparative fit index $(\mathrm{CFI})=0.978$, incremental fit index $(\mathrm{IFI})=0.978$, root mean square error of approximation $(\mathrm{RMSEA})=0.076)$. All items loaded significantly on their corresponding latent construct with the standardized factor loadings higher than 0.7 , thereby providing evidence of good convergent validity, as shown in Table 1. Except that, the AVE of each construct is far greater than the corresponding inter-construct squared correlations which also supports the discriminant validity of international knowledge search, search intensity and innovation performance. 
Table 1 Measurement scales and properties

\begin{tabular}{|c|c|c|}
\hline Constructs/Measurement items & $\begin{array}{c}\text { Standardized } \\
\text { loadings }\end{array}$ & AVE \\
\hline International knowledge search & & \multirow{6}{*}{0.846} \\
\hline 1.Establishing friendly cooperation relationship with foreign customers & 0.898 & \\
\hline $\begin{array}{l}\text { 2.Monitoring daily operation and innovative behavior of foreign competitors } \\
\text { actively }\end{array}$ & 0.893 & \\
\hline 3.Establishing healthy cooperation ties with foreign suppliers or vendors & 0.914 & \\
\hline $\begin{array}{l}\text { 4. Establishing tight cooperation ties with foreign university and research } \\
\text { institutions }\end{array}$ & 0.905 & \\
\hline 5. Establishing tight cooperation ties with foreign innovation intermediary & 0.984 & \\
\hline \multicolumn{2}{|l|}{ Search intensity } & \multirow{4}{*}{0.757} \\
\hline 1. Investing a great deal of effort into gathering potentially valuable information & 0.866 & \\
\hline $\begin{array}{l}\text { 2. Making looking for new information a top priority for how firms would } \\
\text { spend my time }\end{array}$ & 0.889 & \\
\hline $\begin{array}{l}\text { 3. Going out of firms way to find information sources that may have relevant } \\
\text { information }\end{array}$ & 0.855 & \\
\hline \multicolumn{2}{|l|}{ Innovation performance } & \multirow{7}{*}{0.916} \\
\hline 1.The number of new products & 0.955 & \\
\hline 2.The ratio of new products sales to total sales & 0.960 & \\
\hline 3.The speed of new product development & 0.949 & \\
\hline 4.The success ratio & 0.955 & \\
\hline 5.The number of patent applications & 0.968 & \\
\hline 6.The novelty of new product & 0.955 & \\
\hline
\end{tabular}

All standardized coefficient loadings are significant at $\mathrm{p}<0.001$.

$\mathrm{AVE}=$ Average variance extracted for each multi-item construct in the research model.

\section{Empirical Results}

\section{Assessment of the Measures}

Table 2 presents the means, standard deviations, and correlations among the variables examined in the study. International knowledge search $(r=0.436, p<0.01)$ and search intensity $(r=0.192, p<0.01)$ are positively correlated with innovation performance. The results of correlation analysis lay a solid foundation for the upcoming multiple regression analysis.

Table 2. Descriptive statistics and pearson correlations

\begin{tabular}{l|c|c|c|c|c|c|c|c}
\hline & Mean & S. D. & 1 & 2 & 3 & 4 & 5 & 6 \\
\hline 1. FS & 7.559 & 1.400 & 1 & & & & & \\
\hline 2. FA & 15.54 & 9.158 & $0.405^{* *}$ & 1 & & & & \\
\hline 3.R\&D & 0.048 & 0.025 & 0.003 & 0.030 & 1 & & & \\
\hline $4 . \mathrm{IKS}$ & 3.993 & 1.369 & $0.151^{*}$ & 0.026 & $0.250^{* *}$ & 1 & & \\
\hline 5.SI & 4.772 & 1.228 & 0.039 & $0.158^{*}$ & 0.123 & -0.007 & 1 & \\
\hline 6.IP & 3.980 & 1.659 & $0.211^{* *}$ & 0.015 & $0.365^{* *}$ & $0.436^{* *}$ & $0.192^{* *}$ & 1 \\
\hline
\end{tabular}

$* * \mathrm{p}<0.01 ; * \mathrm{p}<0.05$ (two-tailed test).

\section{Multiple Regression Analysis}

Table 3 presents the results of the hierarchical multiple regression models. Model 1 only included controls. Model 2 added the main effects of international knowledge search. Model 3 added the main 
effects of search intensity. Model 4 added the controls, the main effects of international knowledge search, search intensity, the interaction term of international knowledge search and search intensity. To reduce the potential problem of multicolinearity, international knowledge search and search intensity were mean-centered prior to the creation of interaction terms. The results show all the maximal VIF value (variance inflation factor) in four models are far less than 10 which indicates there is no multicolinearity in our analysis.

The results in Model 2 suggest that international knowledge search is positively related to innovation performance $(b=0.328, p<0.001)$. Hypothesis 1 is supported. The results in Model 3 suggest that search intensity is positively related to innovation performance $(b=0.197, \mathrm{p}<0.01)$. Hypothesis 2 is supported. The results in Model 4 suggest that the interaction term of international knowledge search and search intensity is positively related to innovation performance $(b=0.157, p<0.01)$. Hypothesis 3 is supported. Except that, the results of the whole model 4 support hypothesis 1 and hypothesis 2 again.

Table 3. Results of standardized regression analysis

\begin{tabular}{c|c|c|c|c}
\hline & Model 1 & Model 2 & Model 3 & Model 4 \\
\hline FS & $0.253^{* * *}$ & $0.196^{* *}$ & $0.263^{* * *}$ & $0.193^{* *}$ \\
\hline FA & -0.104 & -0.083 & -0.123 & -0.107 \\
\hline Ind 1 & 0.032 & 0.020 & -0.063 & -0.061 \\
\hline Ind 2 & 0.082 & 0.048 & 0.018 & -0.029 \\
\hline Ind 3 & -0.056 & -0.046 & -0.133 & -0.132 \\
\hline Ind 4 & 0.081 & 0.061 & 0.040 & 0.025 \\
\hline Ind 5 & 0.069 & 0.057 & 0.038 & 0.025 \\
\hline R\&D & $0.382^{* * *}$ & $0.297^{* * *}$ & $0.358^{* * *}$ & $0.251^{* * *}$ \\
\hline IKS & & $0.328^{* * *}$ & & $0.307^{* * *}$ \\
\hline SI & & & $0.197^{* *}$ & $0.177^{* *}$ \\
\hline IKS $\times$ SI & & & & $0.157^{* *}$ \\
\hline R & 0.202 & 0.299 & 0.234 & 0.357 \\
\hline F & $6.651^{* * * *}$ & $9.917^{* * *}$ & $7.085^{* * *}$ & $10.432^{* * *}$ \\
\hline Max VIF & 2.190 & 2.191 & 2.473 & 2.497 \\
\hline
\end{tabular}

$* * * \mathrm{p}<0.001 ; * * \mathrm{p}<0.01 ; * \mathrm{p}<0.05$ (two-tailed test).

\section{Discussion and Conclusion}

Open innovation has evolved as an hot topic in recent years. However, existing research on open innovation mainly focus on local knowledge search and ignores to answer the question that how firms search outside. This paper divides the search process into two parts: search selection and search intensity, and investigates the independent and joint impact of international knowledge search and search intensity on innovation performance. The result show that international knowledge search and search intensity are both positively related to innovation performance. The relationship between international knowledge search and innovation performance is positively moderated by search intensity.

This study contributes to open innovation research by demonstrating the importance of international knowledge source, and most importantly uncovering the knowledge search process which demonstrates that search selection should march with search intensity ${ }^{[16]}$. When firms search in the international markets, they should pay enough attention to identify and integrate the knowledge obtained because the complexity of foreign knowledge has surpassed their capacity limit.

The findings of this study offer some important implications for managers. Managers should realize that entering into international market can help firms obtain novel resources and learning opportunity which finally will promote innovation. Most importantly, firms should devote enough attention to international knowledge searching process because of high amount and complexity of foreign knowledge. In view of resource limit, it is difficult for a lot of firms to search seriously both in international markets and local markets, then the appropriate deployment of resources is significant for 
firms to promote innovation. Paying enough attention to international markets is necessary for firms to enhance search efficiency.

\section{Acknowledgement}

This research is financially supported by China Post doctoral Science Foundation (2014M561452).

\section{References}

[1] H. W.Chesbrough. Open innovation: the new imperative for creating and profiting from technology. Cambridge, MA: Harvard Business Press. (2003).

[2] J. Wu. The effects of external knowledge search and ceo tenure on product innovation: evidence from chinese firms. Industrial \& Corporate Change. 23 (2014) 65-89.

[3] K. Laursen, A. Salter. Open for innovation: the role of openness in explaining innovation performance among UK manufacturing firms. Strategic Management Journal. 27 (2006)131-150.

[4] H. Garriga, G. Von Krogh, S. Spaeth, How constraints and knowledge impact open innovation. Strategic Management Journal. 34 (2013) 1134-1144.

[5] J. Chen, Y. Chen, W. Vanhaverbeke, The influence of scope, depth, and orientation of external technology sources on the innovative performance of Chinese firms. Technovation. 31 (2011) 362-373.

[6] D. Kahneman, Attention and effort. Englewood Cliffs, NJ: Prentice Hall. (1973).

W. Ocasio, Attention to attention. Organization Science. 22 (2011) 1286 -1296.

[7] Q. Li, P. G. Maggitti, K. G. Smith, Top management attention to innovation:The role of search selection and intensity in new product introductions. Academy of M anagement Journal. 56 (2013) 893-916.

[8] S. A.Zahra, R. D. Ireland, M. A. Hitt, International expansion by new venture firms: International diversity, mode of market entry, technological learning and performance. Academy of Management Journal. 43 (2000) 925-950.

[9] M. I. Kafouros, N. Forsans, The role of open innovation in emerging economies: Do companies profit from the scientific knowledge of others? Journal of World Business. 47 (2012) 362-370.

[10] J. Wu, Z. Wu, Local and international knowledge search and product innovation: The moderating role of technology boundary spanning. International Business Review. 23 (2014) 542-551.

[11] M. I. Kafouros, P. J. Buckley, J. A. Sharp, C. Wang, The role of internationalization in explaining innovation performance. Technovation. 28 (2008) 63-74.

[12] Y. Zhang, H.Y. Li, Innovation search of new ventures in a technology cluster: The role of ties with service intermediaries. Strategic Management Journal. 31 (2010) 88-109. 